\title{
Relationship between Affect and Achievement in Science and Mathematics in Malaysia and Singapore
}

\author{
${ }^{1} \mathrm{Ng}$, Khar Thoe, ${ }^{2}$ Lay, Yoon Fah, ${ }^{3}$ Areepattamannil, Shaljan, ${ }^{4}$ Treagust, David F. and ${ }^{4}$ Chandrasegaran, A.L.

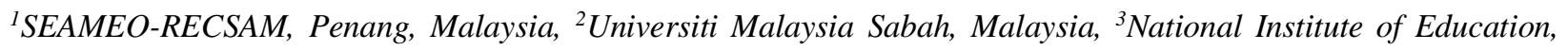 \\ Singapore, ${ }^{4}$ Curtin University, Perth, Australia
}

Background: The Trends in International Mathematics and Science Study (TIMSS) assess the quality of the teaching and learning of science and mathematics among the Grades 4 and 8 students across participating countries.

Purpose: This study explored the relationship between positive affect towards science and mathematics and achievement in science and mathematics among Malaysian and Singaporean Grade 8 students.

Sample: A total of 4,466 Malaysia students and 4,599 Singaporean students from Grade 8 who participated in the Trends in International Mathematics and Science Study (TIMSS 2007) were involved in this study.

Design and method: Students' achievement scores on eight items in the survey instrument that were reported in the TIMSS 2007 were used as the dependent variable in our analysis. Students' scores on four items in the TIMSS 2007 survey instrument pertaining to students' affect towards science and mathematics together with students' gender, language spoken at home, and parental education were used as the independent variables.

Results: Positive affect towards science and mathematics indicated statistically significant predictive effects on achievement in the two subjects for both Malaysian and Singaporean Grade 8 students. There were statistically significant predictive effects on mathematics achievement for the students' gender, language spoken at home and parental education for both Malaysian and Singaporean students with $\mathrm{R}$ square $=0.18$ and 0.21 respectively. However, only parental education showed statistically significant predictive effects on science achievement for both countries. For Singapore, language spoken at home also demonstrated statistically significant predictive effect on science achievement but not for gender. As for Malaysia, both gender and language spoken at home had no statistically significant predictive effects on science achievement.

Conclusions: It is important for educators to consider implementing self-concept enhancement intervention programmes by incorporating 'affect' components of academic self-concept in order to develop students' talents and promote academic excellence in science and mathematics.

Keywords: attitudes; interest and motivation; science and mathematics learning; TIMSS 2007

Running head: Affect and achievement in science and mathematics

\section{Introduction}

Studies related to students' attitudes, interest and motivation in science and mathematics have been the research focus of many educational psychologists and researchers especially in several developing countries with aspiration to produce a critical mass of personnel in science and 
technology related careers and activities. Motivation is a core construct in human behaviour and the starting point for learning. In the education field, it can be explained from the aspect of academic motivation and academic self-concept, the beliefs that people have about their own academic progress (Brunner et al. 2010; Phillips 2007a). The expectancy-value theory explains the two factors contributing to 'academic motivation', i.e. students 'valuing the task', either the outcome or the process of learning and the 'expectations' that they will be successful. Students with 'achievement motivation' (i.e. one aspect of 'valuing the task') learn to show that they can perform better than other people. Students' 'beliefs in their own efficacy' and 'to what they attribute their success and failure to' are the two major issues when discussing 'expecting success'. Self-efficacy is a specific form of theory explaining self-concept, i.e. how individuals see themselves. Academic self-concept is how students view their own abilities and skills in handling academic tasks (Bandura 1977).

In recent years, academic self-concept and its relationship with academic achievement has also been an area of research interest by several educational psychologists (Damrongpanit 2009; Marsh 2003; Marsh and Martin 2010). However, there is still limited research on the effects of the various dimensions, including the affective/motivational dimension (i.e. 'affect') (Arens et al. 2011; Marsh et al. 1999) of academic self-concept on academic achievement especially in specific subjects such as science and mathematics in the Asia-Pacific region. Hence, the purpose of this study was to examine the predictive effects of the 'affect' component of academic self-concept, i.e. the positive affect towards science and mathematics, on the science and mathematics achievement in two Southeast Asian Ministers of Education Organisation (SEAMEO) member countries, i.e. Malaysia and Singapore that participated in the 2007 TIMSS. 


\section{Academic motivation, self-concept and achievement}

The following review of the research literature further explores the nature and key theoretical perspectives of academic motivation that form the basis of the framework that guides this study.

\section{Academic motivation and achievement in science and mathematics}

A number of traits or characteristics which are interrelated or overlap to some extent have been identified as important for 'academic motivation' in order to enhance achievement in science and mathematics learning. For example, highly positively motivated students would find a task inherently enjoyable (intrinsic motivation), have an established long-term interest in particular topics (personal interest), have a desire to fully understand the content (a mastery goal), and believe that success will be related to effort (an attribution). In fact, educational psychologists believe that students' academic motivation is influenced by a number of beliefs, values, interests and attitudes with positive or negative effects. The construct 'belief in own coping ability' (intrinsic motivation), is based on the Expectancy-Value theory which states that beliefs about one's ability to succeed are 'expectancy beliefs', whereas beliefs about the extent to which the task is useful, enjoyable, or relates to one's self-image are 'value beliefs' (Glynn et al. 2007; Palmer 2007; Phillips 2007a; Weiner 1979). Students are believed to be motivated to learn when they value either the outcome or process of learning and they expect that they will be successful. Psychologists believe that if the task is of value (value beliefs) students are expected to have the ability and confidence to succeed in the learning task (expectancy and self-efficacy beliefs). Selfefficacy is a very specific form of 'self-concept' theory proposed by Bandura (1977) that refers to the confidence in one's ability to behave in such a way as to produce a desirable outcome. Self-efficacy makes a difference in how people feel, think and act, such as in 
science/mathematics related learning activities. Hence it is believed that such motivational constructs will indirectly enhance their academic achievement.

\section{Academic self-concept and affect towards science and mathematics learning}

Components of 'self-concept' include physical, psychological, and social attributes, which can be influenced by the individual's attitudes, habits, beliefs and ideas. Self-concept is divided into a 'cognitive' component, known as the 'self-schema', and an 'evaluative' component, 'selfesteem'. Self-esteem is the good opinion of oneself (Atkinson et al. 1993; Hornby 1974). The need to maintain a healthy self-esteem is recognised as a central human motivation in the field of social psychology. More often, 'self-concept' is a term referring to the whole sum of beliefs that people have about themselves. 'Academic self-concept' refers to the mental representation of one's abilities within school or academic settings, or in relation to one's academic progress (Bracken 2009; Brunner et al. 2010).

The development of personality occurs continuously in a lifetime and not in stages. The 'self' consists of all the ideas, perceptions and values that characterise 'I' or 'me' and could be explained from the aspects of 'affect, behaviour, and cognition' (Atkinson et al. 1993; Dweck and Leggett 1988; Lefton 1991). 'Affect' is a psychological term that is literally defined as "a feeling or emotion as distinguished from thought or action; a strong feeling with active consequences; an inclination; inward disposition or influence" (Hornby 1974). Affect in science education is "about interest, motivation, attitudes, beliefs, self-confidence and self-efficacy within science education" (Alsop and Watts 2003, p. 1043). In linguistics, speaker affect is attitude or emotion that a speaker brings to an utterance. Affective forecasting is the process of prediction of how one would feel in response to future emotional events. Studies done by Wilson 
and Gilbert (2003) have shown that people overestimate the strength or reaction to positive and negative life events than they actually would have felt when the event did occur.

The well-adjusted person has a self-concept that is consistent with thought, experience and behaviour; the self is not rigid, but flexible, and can change as it assimilates new experience and ideas (Atkinson et al. 1993). A 'cognitive' question for self-concept may be: How do individuals become themselves, build a self-concept, and uphold a stable sense of identity? An 'affective' (or emotional) question may be: How do people evaluate themselves, enhance their self image, and maintain a secure sense of identity? A 'behavioural' question may be: How do people regulate their own actions and present themselves to others according to interpersonal demands? Educational researchers who are interested in studying the predictive effects of 'affect' towards academic subjects such as science/mathematics would hence address the above questions in their research instruments (Lefton 1991; Phillips 2007a).

\section{Rationale of the study and research questions}

This study examined the predictive effects of positive affect towards science and mathematics on the science and mathematics achievement among Grade 8 students in Malaysia and Singapore that participated in the 2007 TIMSS. TIMSS is an international comparative study designed and sponsored by The International Association for Evaluation of Educational Achievement (IEA) that has been conducted since 1995. It was designed to assess the quality of the teaching and learning of science and mathematics among the Grades 4 and 8 students across participating countries. Singapore joined the TIMSS studies in 1995 at both the fourth and eighth grade levels. But Malaysia joined the program in 1999 only at the eighth grade level. 
Malaysia and Singapore are two out of the eleven countries in the SEAMEO region with a number of similarities and differences in their socio-cultural backgrounds and geographical structures. In terms of population size, Malaysia is about six times larger than Singapore. In terms of land area, Singapore is 470 times smaller than Malaysia, but in terms of per capita income, it is almost six times higher than Malaysia's (Mullis et al. 2000). Both countries consist of three major ethnic groups, i.e. Malays, Chinese and Indians. Hence, multilingualism is also a common characteristic of the two countries. Even though Malay is the national language of both countries (Gary et al. 2008), English is the medium of instruction in Singapore (Mullis et al. 2008) and is also used in the teaching of science and mathematics. In Malaysia however, English was used as the medium of instruction to teach science and mathematics since 2003 but it will be reverted to the use of the Malay language (Bahasa Malaysia) as medium of instruction for these subjects from 2014 onwards.

Despite all these differences in their socio-cultural background, there are some similarities especially from the aspect of the centralised educational systems in both countries. Educational structures and schooling age in both countries are also similar with (1) three years of pre-school starting from age 4, (2) six years of primary schooling starting from age 7, (3) four to five years of secondary schooling starting from age 13, and (4) 2 years of pre-university schooling. There is also not much difference in terms of weekly time allocation for science and mathematics instruction.

A summary of the performance of the two countries in TIMSS $1995-2007$ is provided in Table 1. 
Table 1 TIMSS science and mathematics scores and rank of Malaysia and Singapore from 19952007

\begin{tabular}{lccccc}
\hline & $\begin{array}{c}\text { No. of } \\
\text { participating } \\
\text { countries }\end{array}$ & $\begin{array}{c}\text { Salaysia } \\
\text { (rank) }\end{array}$ & $\begin{array}{c}\text { Singapore } \\
(\text { rank })\end{array}$ & $\begin{array}{c}\text { Malaysia } \\
\text { (rank) }\end{array}$ & $\begin{array}{c}\text { Singapore } \\
\text { (rank) }\end{array}$ \\
\cline { 3 - 6 } TIMSS 1995 & 45 & - & 607 & - & 643 \\
TIMSS 1999 & \multirow{2}{*}{38} & 492 & 568 & 519 & $(1 \mathrm{st})$ \\
& \multirow{2}{*}{46} & $(22 \mathrm{nd})$ & $(2 \mathrm{nd})$ & $(16 \mathrm{th})$ & $(1 \mathrm{st})$ \\
TIMSS 2003 & 510 & 578 & 508 & 605 \\
TIMSS 2007 & \multirow{2}{*}{59} & $(21 \mathrm{st})$ & $(1 \mathrm{st})$ & $(10 \mathrm{th})$ & $(1 \mathrm{st})$ \\
& & 471 & 567 & 474 & 593 \\
& & $(21 \mathrm{st})$ & $(1 \mathrm{st})$ & $(20 \mathrm{th})$ & $(3 \mathrm{rd})$ \\
\hline
\end{tabular}

Although a growing body of research emphasises the influences of socio-cultural factors on the academic achievement of secondary school students from the previous TIMSS studies, there is a dearth of research on the impact of psychological constructs, such as the affect component of academic self-concept, on academic achievement especially in the Southeast Asian region for TIMSS in 2007. For example, a study was conducted to explore the variation in mathematics achievement as a function of student- and school-level differences among Malaysian ( $\mathrm{N}=5,314$ students nested within 150 schools $)$ and Singaporean $(\mathrm{N}=6,018$ students nested within 164 schools) Grade 8 students who participated in TIMSS 2003. The findings revealed that at the student level, mathematics self-concept was found to be the most influential factor on achievement of students from both Malaysia and Singapore (Najib et al. 2011). The study by Noor Azina and Halimah (2009) also found that mathematics achievement in Malaysia increased significantly with students' aspirations, perception of being safe at school, selfconfidence in learning mathematics and time spent on mathematics homework. However, not much research has been conducted for science achievement based on TIMSS. 
Thus, in light of scarcity of empirical research on the effects of the affect component especially of science self-concepts on science achievement particularly for the recent TIMSS in 2007, the present study addressed the three following research questions (RQs):

Research Question 1: How well does positive affect towards science contribute towards the science achievement of Malaysian and Singaporean Grade 8 students?

Research Question 2: How well does positive affect towards mathematics contribute towards the mathematics achievement of Malaysian and Singaporean Grade 8 students?

Research Question 3: What is the contribution of demographic variables like gender, language spoken at home and parental education to students' achievement in science and mathematics?

Furthermore the attitudes of students towards learning science and mathematics, their interest in these subjects as well as their motivation to learn are all important considerations because there is an urgent need to have a continuous supply of scientists and technocrats to meet the rapidly developing economy of Malaysia. The same need is also true for Singapore which is a developed country with lack of natural resources that depends entirely on its human capital to maintain and further develop its economy. It is therefore imperative that information about students' affect towards science and mathematics learning be made readily available to teachers so that they are able to plan and implement instructional programmes that have the capacity to further enhance the attitudes, interests and motivation of students in science and mathematics.

\section{Methodology}

\section{Samples}

The samples of students for this study were drawn from the dataset of Malaysian and Singaporean Grade 8 students who participated in TIMSS 2007, the fourth in a series of 
comparative international studies that aims at assessing the mathematical and science performance of both Grades 4 and 8 students. About 425,000 students from 59 countries participated in TIMSS 2007. The number of Grade 8 students from Malaysia was 4,466 (male = $2,104$, female $=2,362)$ and Singapore was 4,599 $($ male $=2,353$, female $=2,246)($ IEA, 2009a).

\section{Measures}

\section{Response/Dependent/Outcome Variables}

The dependent variables in the study are the Grade 8 science achievement score (five plausible values) and mathematics achievement score (five plausible values) on the TIMSS 2007 assessment. "Plausible values are multiple imputations of the unobservable latent achievement for each student" (Wu 2005, p.114). These values were developed by TIMSS 2007 as a computational approximation to obtain consistent and precise estimates of students' ability because the students were administered with too few items in each specific content area (IEA 2009a). The science and mathematics achievement scores were reported on a scale from 0 to 1,000, with the TIMSS scale average set at 500 and standard deviation set at 100 (Olson et al. 2008). Statistical Packages for the Social Sciences (SPSS) version 17 was used as plug-in along with IEA International Database (IDB) analyzer Version 2.0 (IEA 2009b) to run the models for each of the five plausible values to produce their average values and correct standard errors (s.e.).

\section{Manipulated/Independent/Predictor Variables}

There are four items in the TIMSS 2007 survey instrument pertaining to students' affect towards each of science and mathematics as measure of the Grade 8 students' science and mathematics self-concept especially the affect component. All items were rated on a four-point Likert-type scale ranging from 1 (strongly disagree) to 4 (strongly agree). Negatively-worded items (i.e. 
science is boring, mathematics is boring) were reverse-scored. The complete instrument is shown in Figure 1.

\begin{tabular}{|c|c|c|c|c|c|}
\hline $\begin{array}{l}\text { Item } \\
\text { no. }\end{array}$ & Items & 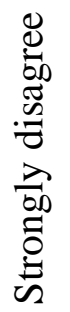 & 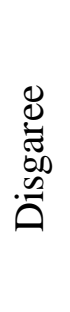 & $\begin{array}{l}\stackrel{8}{\leftrightarrows} \\
\stackrel{50}{\longleftarrow}\end{array}$ & 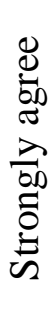 \\
\hline \multirow[b]{2}{*}{1} & \multirow{2}{*}{$\begin{array}{l}\text { Positive affect towards science } \\
\text { I like science }\end{array}$} & \multirow[b]{2}{*}{1} & \multirow[b]{2}{*}{2} & \multirow[b]{2}{*}{3} & \multirow[b]{2}{*}{4} \\
\hline & & & & & \\
\hline 2 & I enjoy learning science & 1 & 2 & 3 & 4 \\
\hline 3 & I would like to take more science in school & 1 & 2 & 3 & 4 \\
\hline 4 & Science is boring & 1 & 2 & 3 & 4 \\
\hline \multirow[b]{2}{*}{5} & \multirow{2}{*}{$\begin{array}{l}\text { Positive affect towards mathematics } \\
\text { I like mathematics }\end{array}$} & & & & \\
\hline & & 1 & 2 & 3 & 4 \\
\hline 6 & I enjoy learning mathematics & 1 & 2 & 3 & 4 \\
\hline 7 & I would like to take more mathematics in school & 1 & 2 & 3 & 4 \\
\hline 8 & Mathematics is boring & 1 & 2 & 3 & 4 \\
\hline
\end{tabular}

Figure 1 TIMSS 2007 survey instrument pertaining to students' affect towards science and mathematics

Factor analysis with the maximum-likelihood extraction and Varimax rotation was performed on all the eight items for the whole sample, and the output is listed in Table 2. 
Table 2 Factor loadings of Exploratory Factor Analysis

Factor Loadings

Item

nos.

Subscales and Items

Malaysia Singapore

Factor 1 Factor 2 Factor 1 Factor 2

\section{Positive affect towards science}

1. I like science

2. I enjoy learning science

0.878

0.918

3. I would like to take more science in school

0.872

0.915

0.735

0.852

4. Science is boring

0.709

0.804

5. Positive affect towards mathematics

$\begin{array}{lll}\text { 6. I like mathematics } & 0.876 & 0.909\end{array}$

7. I enjoy learning mathematics $\quad 0.873 \quad 0.901$

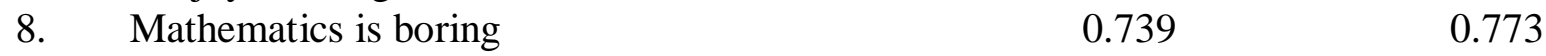

I would like to take more mathematics in $\quad 0.656 \quad 0.851$ school

Two factors were extracted from the eight items, and these two factors accounted for $66 \%$ of the variance for the Grade 8 Malaysian students and $76 \%$ for the Singaporean students. Loadings of all variables on factors were above the cut-off point of 0.45 (20\% of variance). The factor solutions met multiple additional criteria such that each factor contained a minimum of three items, exhibited sufficient internal consistency, and was interpretable. Cronbach's alpha (CA) was used to measure the internal consistency of the scale items. This was to measure how well each individual item in a subscale correlated with the sum of the remaining items with a recommended acceptable range of CA between 0.7 and 0.9 . Moreover, an item may be deleted if it had low Corrected Item-Total Correlation (e.g. below 0.3 or 0.2) and high 'Alpha if Item Deleted' considering various other factors (Creswell 2005; Phillips 2007b). Factor Analysis (FA) was conducted with computation of the correlations between the items. Factorability was ensured by examining Kaiser-Meyer-Olkin (KMO) measure of sampling adequacy and Bartlett's test of sphericity to check whether or not the data are likely to factor well, based on correlations and 
partial correlations. If KMO is greater than 0.6 as well as Bartlett's test is large and significant, then factorability is assumed. Then the factors were extracted using Principal Component Analysis (PCA), with Total Variance Explained including Eigenvalues (more than one), Extraction and Rotation Sums of Squared Loadings and the Scree Test. Only the factors having latent roots or Eigenvalues greater than 1 were considered significant. Varimax rotation was conducted to make the factors more interpretable and reduce the number of complex variables by suppressing absolute values less than 0.35. Items with double and triple loadings were considered to be deleted or modified (Bryman and Cramer 1998; Creswell 2005; Hair et al. 1998; Phillips 2007b).

In addition the percentage of variance criterion that is an approach based on achieving a specified cumulative percentage of total variance extracted by successive factors was observed. This was to enable practical significance of the derived factors by ensuring that they explained at least a specified amount of variance. In the social sciences (including educational settings), where information is often less precise, a solution that accounts for 60 percent or less of the total variance was considered as satisfactory (Hutcheson and Sofroniou 1999 in Phillips 2007b). With the sample size in the range of 150 to 185 , only items with factor loading 0.45 and above were retained (Creswell 2005; Phillips 2007b). In this study, the two factors identified were 'positive affect towards science' (4 items, i.e. 'I like science, I enjoy learning science, I would like to take more science in school and Science is boring') and 'positive affect towards mathematics' (4 items, i.e. 'I like mathematics, I enjoy learning mathematics, I would like to take more mathematics in school and Mathematics is boring'). 
The student demographic variables were gender $(0=$ female, $1=$ male $)$, language spoken at home (speaking the language of the assessment at home) $(1=$ never to $4=$ always), and parental education $(1=$ less than lower secondary education to $5=$ university education).

\section{Results}

Table 3 summarises the correlations between the science and mathematics achievement (dependent/outcome variables) and gender, language spoken at home, parental education, positive affect towards science, and positive affect towards mathematics (independent/predictor variables). The correlation between positive affect towards science and science achievement is $0.2205(\mathrm{~s} . \mathrm{e}=0.0253)$ for the Malaysian samples and $0.2625(\mathrm{~s} . \mathrm{e}=0.0190)$ for the Singaporean samples. The correlation between positive affect towards mathematics and mathematics achievement is $0.2070(\mathrm{~s} . \mathrm{e}=0.0217)$ for the Malaysian samples and $0.3061(\mathrm{~s} . \mathrm{e}=0.0176)$ for the Singaporean samples. Multicollinearity was examined and it was found that none of the correlation coefficients was $\geq 0.70$. Moreover, the 'tolerance' values were greater than 0.50 and the variance inflation factors were less than 2 (Pallant 2001; Tabachnick and Fidell 2001).

Table 3 Correlation between positive affect towards science and mathematics with science and mathematics achievement

\section{Correlation}

\begin{tabular}{cccc}
\hline \multicolumn{2}{c}{ Malaysia } & \multicolumn{2}{c}{ Singapore } \\
\hline $\begin{array}{c}\text { Science } \\
\text { achievement }\end{array}$ & $\begin{array}{c}\text { Mathematics } \\
\text { achievement }\end{array}$ & $\begin{array}{c}\text { Science } \\
\text { achievement }\end{array}$ & $\begin{array}{c}\text { Mathematics } \\
\text { achievement }\end{array}$ \\
$\begin{array}{c}0.2205 \\
\text { s.e. }=0.0253)\end{array}$ & - & $\begin{array}{c}0.2625 \\
(\text { s.e. }=0.0190)\end{array}$ & - \\
- & $\begin{array}{c}0.2070 \\
(\text { s.e. }=0.0217)\end{array}$ & - & 0.3061 \\
& & &
\end{tabular}


As shown in Table 4, there were statistically significant predictive effects on mathematics achievement for the students' demographic variables (i.e. gender, language spoken at home and parental education) for both Malaysian and Singaporean Grade 8 students with $\mathrm{R}$ square $=0.18$ and 0.21 respectively. However, only parental education had statistically significant predictive effects on science achievement for both countries. For Singapore, language spoken at home also indicated statistically significant predictive effects on science achievement but not for gender. As for Malaysia, both gender and language spoken at home did not show statistically significant predictive effects on science achievement.

\section{Discussion}

This article examined the predictive effects of positive affect towards science and mathematics on science and mathematics achievement among Malaysian and Singaporean Grade 8 students in the 2007 TIMSS.

\section{Positive affect towards science and science achievement}

As shown in Table 3, both the Malaysian and Singaporean Grade 8 students (in response to RQ 1) who reported high positive affect towards science performed significantly better in science. The findings suggested that boosting students' positive affect towards science may help to improve their achievement in science.

\section{Positive affect towards mathematics and mathematics achievement}

However, (in response to RQ 2) as also shown in Table 3 only Singaporean Grade 8 students who reported high positive affect towards mathematics performed significantly better in mathematics. 
Table 4 Ordinary Least Squares (OLS) Regression Analyses Predicting Science and Mathematics Achievement among Malaysian $(\mathrm{N}=4,466)$ and Singaporean $(\mathrm{N}=4,599)$ Grade 8 Students

\begin{tabular}{|c|c|c|c|c|c|c|c|c|}
\hline & \multicolumn{4}{|c|}{ Malaysia } & \multicolumn{4}{|c|}{ Singapore } \\
\hline & \multicolumn{2}{|c|}{ Science } & \multicolumn{2}{|c|}{ Mathematics } & \multicolumn{2}{|c|}{ Science } & \multicolumn{2}{|c|}{ Mathematics } \\
\hline & estimate & s.e. & estimate & s.e. & estimate & s.e. & estimate & s.e. \\
\hline Constant/Intercept & 305.95 & 26.16 & 400.27 & 20.02 & 335.27 & 15.36 & 402.25 & 12.69 \\
\hline Gender & -8.41 & 4.80 & $-9.27 *$ & 3.74 & -7.18 & 4.31 & $12.35^{*}$ & 4.02 \\
\hline Language & -3.57 & 4.00 & $-17.11 *$ & 3.21 & $16.48 *$ & 2.31 & $8.69 *$ & 2.14 \\
\hline Parental education & $18.61 *$ & 1.95 & $17.06^{*}$ & 1.84 & $22.28 *$ & 1.76 & $18.69 *$ & 1.50 \\
\hline Positive affect towards science & $29.84 *$ & 3.54 & $-4.31 *$ & 3.12 & $32.76^{*}$ & 2.79 & $11.24 *$ & 2.17 \\
\hline Positive affect towards mathematics & $12.55^{*}$ & 3.88 & $32.43 *$ & 2.84 & $10.39 *$ & 2.30 & $31.88^{*}$ & 2.20 \\
\hline Multiple correlation, $\mathrm{R}^{2}$ & & 0.14 & & 0.18 & & 0.23 & & 0.21 \\
\hline
\end{tabular}


In contrast, the Malaysian Grade students' positive affect towards mathematics had negative predictive effects on their mathematics learning. This suggested that boosting students' positive affect towards mathematics may not help to improve the Malaysian Grade 8 students' achievement in mathematics and may even adversely affect their achievement in mathematics.

Students' demographic variables and science/mathematics achievement

In response to RQ 3, the results indicate that students' demographic variables (i.e. gender, language at home, and parental education) showed statistically significant predictive effects on mathematics achievement for both Malaysian and Singaporean Grade 8 students with $\mathrm{R}$ square $=$ 0.18 and 0.21 respectively. The effect sizes were considered modest based on the Muijs' (2004) guideline. However, only parental education had statistically significant predictive effects on science achievement for both countries. For Singapore, language spoken at home also had statistically significant predictive effects on science achievement but not for gender. As for Malaysia, both gender and language spoken at home did not have statistically significant predictive effects on science achievement.

\section{Implications for practice}

The findings of this study suggest some important implications for classroom practice among science/mathematics teachers as well as for parents. Apart from providing input for the teaching of science and mathematics curricula through student-centred learning programmes incorporating Pedagogical Content Knowledge (PCK), there is also an urgent need to boost students' positive affect towards science and mathematics learning.

Educational psychologists believe that emotions drive the threesome of attention, meaning and memory that basically sums up the whole process of learning that involves 
attending to information, constructing meaning, and storing in memory. There is growing evidence to suggest that emotions assist in both evaluating and integrating information and experiences (Jensen 1988 in Phillips 2007a). Emotions related to competence, self-assurance, fear, frustration, and the like, each play a role in how a student approaches learning. 'Affect' is a feeling or emotion with active consequences. Moreover, emotions relate to students' learning abilities and how they interact with others is highly emotive. Positive interactions greatly enhance opportunities for learning while negative responses can virtually shut down learning for affected students. According to social constructivist and socio-cultural theories that advocate much learning is social in nature, positive experiences (with other fellow teachers and students) in the learning environment will greatly enhance the push towards learning. Hence, science and mathematics educators have to recognise that the students come to the classrooms with varying emotions and predispositions, especially when learning more difficult subjects such as science and mathematics. How students perceive the teacher's emotion has an impact on them. For example, if learners thought that they were perceived by teachers to be dumb, incapable, lazy and uninterested, there is strong likelihood that they will act accordingly and felt alienated, hence stop learning and perhaps drop out (Phillips 2007a).

There is mounting evidence that self-concept enhancement intervention programmes would help to improve self-concepts of adolescents in educational settings (O'Mara, Green and Marsh 2006; O’Mara, Marsh, Craven and Debus 2006). Teachers need to take care of how they respond to learners, to personalise their communications (e.g. ask individual learner to relate learning to real life or past experience, hence making the interpersonal aspects of the content more emotionally accessible and enhance learning). They should not hesitate to express their own emotions (saying expressions such as 'felt happy or really impressed by students' 
achievement'). They need to show enthusiasm for the content and for learning, to encourage their understanding by helping them personally create meaning from class material. They need to point out success and give them goals to achieve their learning, hence providing emotional and social support for their learning (Phillips 2007a). Students need to be motivated regularly. When they are intrinsically motivated, they tend to learn better in school and become more creative on tasks requiring conceptual understanding (Niemiec and Ryan 2009).

Having only self-concept enhancement intervention programmes may not be effective in improving students' achievement in science and mathematics. For example, skills training interventions need to be designed and implemented in conjunction with self-concept enhancement interventions (O'Mara, Green and Marsh 2006). Teacher autonomy support may also need to be supplemented with parental autonomy support or involvement. The extent and form of parental involvement is strongly influenced by family social class, maternal level of education, material deprivation, maternal psycho-social health and single parent status and, to a lesser degree, by family ethnicity. Research shows that parental involvement in the form of 'athome good parenting' has a significant positive effect on children's achievement and adjustment even after all other factors influencing attainment have been taken out of the equation.

Unlike controlling parenting, autonomy-supportive parenting i.e., promotion of children's volitional functioning (Soenens et al. 2007) is associated with more positive psychological, developmental, and educational outcomes in adolescents, including improved academic achievement (Soenens and Vansteenkiste 2005), greater academic motivation, and higher levels of subjective well-being (Chirkov and Ryan 2001). Parental involvement takes many forms including good parenting in the home, provision of a secure and stable environment, intellectual stimulation, parent-child discussion, good models of constructive social and educational values 
and high aspirations relating to personal fulfillment and good citizenship, contact with schools to share information, participation in school events, participation in the work of the school and participation in school governance (Desforges and Abouchaar 2003). Autonomy-supportive parenting behaviours may include, among others, taking children's perspectives and viewpoints, encouraging and supporting children's initiatives and autonomous problem-solving with offering of children's choices (Grolnick et al. 2009).

In conclusion, this study has revealed evidence that students' positive affect towards science and mathematics learning may play a key role in shaping their achievement in science and mathematics. Educators should seriously consider implementing self-concept enhancement intervention programmes and redesign interventions by incorporating 'affect' components of academic self-concept to develop students' talents and promote their academic excellence in science and mathematics. In view of the progressive teacher education programmes in both countries as well as the general concern of parents for their children's success in science and mathematics in particular, teacher educators from both countries should support the reform effort of such intervention programmes in their curriculum.

\section{References}

Alsop, S. and Watts, M. 2003. Science education and affect. International Journal of Science Education 25, no. 9: 1043-1047.

Arens, A. K., Yeung, A. S., Craven, R. G. and Hasselhorn, M. 2011. The twofold multidimensionality of academic self-concept: Domain specificity and separation between competence and affect components. Journal of Educational Psychology 103, no. 4: 970-981. 
Atkinson, R. L., Atkinson, R. C., Smith, E. E. and Bem, D .J. 1993. Introduction to Psychology. 11th Edition. Fort Worth, TX: Harcourt Brace Jovanich, Inc.

Bandura, A. 1977. Social learning theory. Englewood Cliffs, NJ: Prentice-Hall.

Bracken, B. A. 2009. Positive self-concepts. In Handbook of positive psychology in the schools, ed. R. Gilman, E. S. Huebner \& M. J. Furlong, 89-106. New York: Routledge.

Brunner, M., Keller, U., Dierendonck, C., Reichert, M., Ugen, S., Fischbach, A. and Martin, R. 2010. The structure of academic self-concepts revisited: The nested Marsh/Shavelson model. Journal of Educational Psychology 102: 964-981.

Bryman, A. and Cramer, D. 1998. Quantitative data analysis with SPSS for Windows: A guide for social scientists. London: Routledge.

Chirkov, V. I. and Ryan, R. M. 2001. Parent and teacher autonomy-support in Russian and U.S. adolescents: Common effects on well-being and academic motivation. Journal of Cross Cultural Psychology 32: 618-635.

Creswell, J. W. 2005. Educational research: Planning, conducting and evaluating quantitative and qualitative research, 2nd edition. Upper Saddle River, New Jersey: Pearson Education, Inc.

Damrongpanit, S. 2009. The study of growth between academic self-concept, nonacademic selfconcept and academic achievement of ninth-grade students: A multiple group analysis. Research in Higher Education Journal. [Retrieved from http://www.aabri.com/manuscripts/09309.pdf on 10 February 2012]

Desforges, C. and Abouchaar, A. 2003. The impact of parental involvement, parental support and family education on pupil achievements and adjustment: A literature review. Research report No. RR433. Queen's Printer: Department for Education and Skills. [Retrieved from 
http://www.bgfl.org/bgfl/custom/files_uploaded/uploaded_resources/ 18617/Desforges.pdf on 11 Feb. 2012]

Dweck, C. S. and Leggett, E. L. 1988. A social-cognitive approach to motivation and personality. Psychological Review 95, no.2: 256-273.

Gary, Q., Goh, K. H., Yen, Y. P., Liu, Y. M., Tan, Q. L., Chin, T. Y., et al. 2008. In I. V. S. Mullis, Martin. M. O, Olson. J. F, Berger. D. R, Milne. D \& Stanco, G. M (Eds.), TIMSS 2007 Encyclopedia: A Guide to Mathematics and Science Education Around the World (Vol. 2).

Glynn, S. M., Taasoobshirazi, G., and Brickman, P. 2007. Non-science majors learning science: A theoretical model of motivation. Journal of Research in Science Teaching 44, no. 8: 10881107.

Grolnick, W. S., Friendly, R. and Bellas, V. 2009. Parenting and children's motivation at school. In Handbook of motivation at school, eds. K. R. Wentzel \& A. Wigfields, 279-300. Mahwah, N.J.: Erlbaum.

Hair, J. F., Anderson, R. E., Tatham, R. L., and Black, W. C. 1998. Multivariate data analysis: With readings. Amazon.com [Retrieved from http://getcited.net/cits/PP/1/PUB/103388996 on 20 Oct. 2011]

Hornby, A.S. (Ed.) 1974. Oxford advanced learner's dictionary of current English. Revised 3rd. ed. Oxford, UK: Oxford University Press.

IEA. 2009a. TIMSS 2007 international mathematics and science reports. International Association for the Evaluation of Educational Achievement (IEA). [Retrieved from http://timss.bc.edu/TIMSS2007/intl_reports.html on 2 Feb. 2011] 
IEA. 2009b. IEA IDB Analyzer (Version 2) [Computer software]. [Retrieved from http://www.iea.nl/iea_studies_datasets.html on 2 Feb. 2011]

Lefton, L. A. 1991. Psychology. 4th ed. Boston: Allyn and Bacon.

Marsh, H. W. 2003, November. A reciprocal effects model of the causal ordering of academic self-concept and achievement. Paper presented at NZARE AARE Conference, Auckland, New Zealand.

Marsh, H. W. and Martin, A. J. 2010. Academic self-concept and academic achievement: Relations and causal ordering. British Journal of Educational Psychology 81: 59-77.

Marsh, H. W., Craven, R. G. and Debus, R. 1999. Separation of competency and affect components of multiple dimensions of academic self-concept: A developmental perspective. Merrill-Palmer Quarterly 45:567-601.

Muijs, D. (2004). Doing Quantitative Research in Education with SPSS. London: Sage.

Mullis, I. V. S., Martin, M. O., and Foy, P. 2008. TIMSS 2007 International Mathematics Report: Chestnut Hill, MA: TIMSS \& PIRLS International Study Center, Boston College. [Retrieved from http://timss.bc.edu/timss2007/intl_reports.html on 22 February 2012]

Mullis, I. V. S., Martin, M. O., Gonzalez, E. J., Gregory, K. D., Garden, R. A., O'Connor, K.M., Chrostowski, S.J., and Smith, T.A. 2000. TIMSS 1999 International Mathematics Report. The International Association for the Evaluation of Educational Achievement (IEA). . Chestnut Hill, MA: The International Study Center, Boston College [Retrieved from http://timssandpirls.bc.edu/timss1999i/math_achievement_report.html on 22 February 2012]

Najib, M. A. G., Rohani O. and Ebrahim M. 2011. Multilevel analysis of achievement in mathematics of Malaysian and Singaporean students. Journal of Educational Psychology and Counseling 2: 285-304. 
Niemiec, C. and Ryan, R. 2009. Autonomy, competence, and relatedness in the classroom. Theory and Research in Education 7: 133-144.

Noor Azina, I. and Halimah, A. 2009. Mathematics achievement among Malaysian students: What can they learn from Singapore? International Education Studies, Vol.2, No.1, February 2009. [Retrieved from http://www.ccsenet.org/journal.html on 2 Feb. 2012]

Olson, J. F., Martin, M. O. and Mullis, I. V. S. (Eds.).2008. TIMSS 2007 technical report. Chestnut Hill, MA: TIMSS \& PIRLS International Study Centre.

O’Mara, A. J., Green, J. and Marsh, H. W. 2006. Administering self-concept interventions in schools: No training necessary? A meta-analysis. International Education Journal 7: 524533.

O’Mara, A. J., Marsh, H. W., Craven, R. G. and Debus, R. 2006. Do self-concept interventions make a difference? A synergistic blend of construct validation and meta-analysis. Educational Psychologist 41:181-206.

Pallant, J. 2001. SPSS survival manual: A step-by-step guide to data analysis using SPSS for Windows (Version 10). Crows Nest NSW, Australia: Allen and Unwin. [Retrieved from http://books.google.com.my/books?id=j1Q7H46y1rYC\&printsec=frontcover \&source $=g b s \_g e \_s u m m a r y \_r \& c a d=0 \# \mathrm{v}=$ onepage $\& q \& \mathrm{f}=$ false on 22 February 2012]

Palmer, D. 2007. What is the best way to motivate students in science? Teaching Science 53, no. 1: $38-42$.

Phillips, J. A. 2007a. Psychology of learning and instruction. Kuala Lumpur, Malaysia: UNITEM Sdn. Bhd.

Phillips, J. A. 2007b. HMEF 5014: Education research methodology. Kuala Lumpur, Malaysia: UNITEM Sdn. Bhd. 
Soenens, B. and Vansteenkiste, M. 2005. Antecedents and outcomes of self-determination in three life domains: The role of parents' and teachers' autonomy support. Journal of Youth and Adolescence 34: 589-604.

Soenens, B., Vansteenkiste, M., Lens, W., Luyckx, K., Goossens, L., Beyers, W. and Ryan, R.M. 2007. Conceptualizing parental autonomy support: Adolescent perceptions of promotion of independence versus promotion of volitional functioning. Developmental Psychology 43: 633-646.

Tabachnick, B. G. and Fidell, L. S. 2001. Using multivariate statistics. Boston: Allyn \& Bacon.

Weiner, B. 1979. A theory of motivation for some classroom experiences. Journal of Educational Psychology 71, no.1: 3-25.

Wilson, T. D. and Gilbert, D. T. 2003. Affective Forecasting. Advances in Experimental Psychology 35: 345-411.

Wu, M. L. 2005. The role of plausible values in large-scale surveys. Studies in Educational Evaluation 31: 114-128. 